\title{
BROWNFIELDY V KARVINÉ: Př ILEC̣TOST NEBO HROZBA?
}

BROWNFIELDS IN KARVINÁ: OPPORTUNITY OR THREAT?

\author{
Mgr. Stanislav MARTINÁT ${ }^{1}$ \\ BC. KATEř INA CYRO@OÁ̃ \\ Mgr. Petr DVOř ÁK, PH.D. ${ }^{1}$ \\ Mgr. Petr KLUSÁLEK, Ph.D. ${ }^{3}$
${ }^{I}$ Odd Dení environmentální geografie ${ }^{1}$ Department of environmental geography \begin{tabular}{l|l} 
Ústav geoniky $A V L R, v . v . i$. & Institute of Geonics $A S C R, v . v . i$.
\end{tabular}
$\bowtie$ Studentská 176870800 Ostrava, Czech Republic
E-mail:martinat@geonika.cz,dvorak@geonika.cz

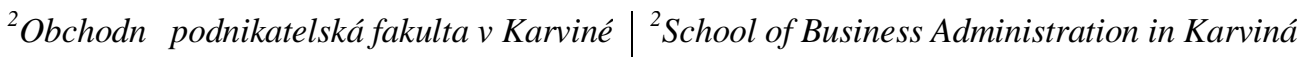 Slezská univerzita v Opav $\rceil$ Silesian University in Opava
$\triangle$ Univerzitní nám $\bigcap_{\text {tí }}$ 1934/3, 73340 Karviná, Czech Republic E-mail:O120925@opf.slu.cz.
${ }^{3}$ Odd hení environmentální geografie $^{3}$ Department of environmental geography \begin{tabular}{l|l} 
Ústav geoniky $A V L R$, v. v. $i$. & Institute of Geonics $A S C R, v . v . i$.
\end{tabular} $\triangle$ Drobného 28, 60200 Brno, Czech Republic E-mail:klusacek@geonika.cz

\begin{abstract}
Anotace
Brownfieldy jsou stále více diskutovaným tématem mezi výzkumníky i veŚsjnou správou. Zvláğn $v$ periferních oblastech a v regionech postiǵených strukturálními zm ņami je problém brownfieldT sohledem na jejich omezenou atraktivitu pro investory velmi specifický. PŚísp円ek se snağ́

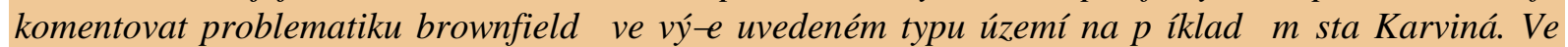
své teoretické !̣ásti pŚisp \ek diskutuje nad ekonomickými, sociálními a environmentálními aspekty regenerace brownfieldT, na coǵnavazuje prostorová analýza thyto ploch na území Karviné, v jejimǵ rámci zkoumána jejich velikost, pŚedchozí vyugótí, typ vlastnictví, kontaminace a umísthịi v rámci

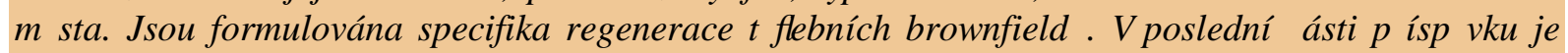

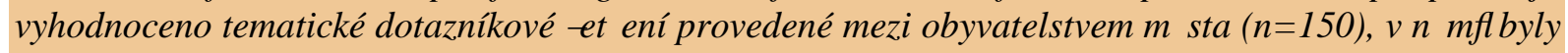
zjiğŠsvány preference budoucího vyuğití brownfieldT a obecn円 percepce thrhto ploch místními

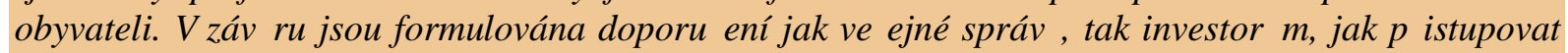
$k$ problematice brownfieldT.
\end{abstract}

\section{Klị̂lová slova}

brownfieldy, Karviná, L̦eská republika, regenerace

\section{Annotation}

Brownfields are increasingly discussed topic among researchers and public administration representatives as well. Especially in peripheral areas and in regions affected by structural changes is an issue of brownfields due to their limited attractiveness for investments very specific. This paper aims to comment the issue of brownfields in the above type of area on the example of city of Karviná. The theoretical part of the paper discusses the economic, social and environmental aspects of brownfield regeneration. Then spatial analysis of these areas brownfields on the area studied city is 
carried on from the point of view of their size, previous use, type of ownership, contamination and location within the city. The specifics of regeneration of mining brownfields are then formulated. In the last part of the paper thematic survey conducted among the population of the city of Karvina $(n=$ 150) is evaluated. The survey aimed to determine preferences for future use of brownfields and general perception of these areas by local population. Within the conclusion recommendations on how public administration and investors should approach the issue of brownfields, are formulated.

Key words

brownfieldy, Karviná, Czech Republic, regeneration

JEL classification: 018

\section{Úvod}

Problematika regenerace brownfieldT je stále !̣astநi diskutovaným tématem jak ze strany zástupcT veŚejné a státní správy, tak i ze strany výzkumníkT. Tímto problémem za bývají jak geografové, ekonomové, sociologové, urbanisté , tak i technicky orientovaní vĐlci. Nicmén円i samotné spektrum

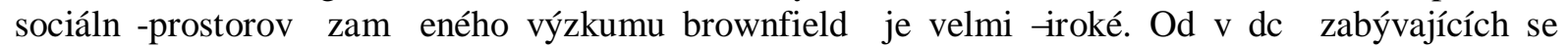
shromaǵnováním informací o brownfieldech a tvorbou jejich databází (napŚS Vojvodíková et al. 2011), pŚses studie analyzující proces regenerace brownfieldT a pŚstupy veŚjné správy v rTzných regionech (napŚ Klusál ek et al. 2011) !̣ i státech, aǵ po výzkumníky, kteŚ se s ohledem na limitované zdroje pro regeneraci brownfields vhují jejich prioritizaci !̣ i klasifikaci (Chrysochoou et al., 2009; Doleǵelová et al., 2014). Z pohledu geografa je nezbytné konstatovat, ǵe ke vǵem uvedeným tématTm geografie jako vhla svými poznatky o prostorových souvislostech a vztazích mezi pŚrodními a sociáln円ekonomickými sloğkami krajinné sféry významn円 pŚspívá. PŚstoǵe geografický (lokalizal ní) kontext regenerace brownfields bývá ! asto podceRován, je moǵné Ści, ǵe prostorový aspekt regenerace brownfieldT je velmi dTleǵitý (Frantál, et al. 2013).

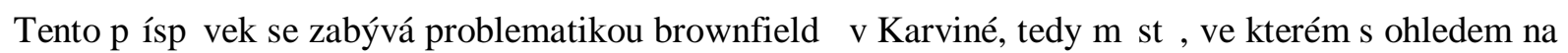
svou prTmyslovou historii posledních více neǵ 150 let nalezneme pozTstatky prTmyslových a

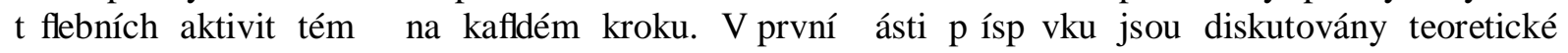
koncepty související s regenerací tḩhto ploch, druhá !̣ást je vĐhována pŚpadové studii, která analyzuje hybné síly vzniku brownfieldT v Karviné, jejich prostorové rozmísthí a výhledy na jejich regeneraci. Ve tŚtí !̣ásti pŚspクjku jsou analyzovány vybrané výsledky anketárního getŚní vhovaného percepci brownfieldT, které bylo realizováno mezi obyvateli $\mathrm{m}$ hta. V záv円el né ! ásti jsou formulována doporul ení pro regeneraci brownfieldT v Karviné.

Národní strategie regenerace brownfieldT (CzechInvest, 2008) hovoŚ o brownfieldech jako o nemovitostech (pozemcích, objektech, areálech), jeǵ jsou nedostate!̣n $\eta$ vyuğivány, zanedbány a mohou být i kontaminovány. Vznikají jako pozTstatek prTmyslové, zemßịnské, reziden! ní, vojenské !̣i jiné aktivity. Jmenovaná strategie také upozorŔuje, ǵe brownfield nelze vhodnク a efektivnク vyuğ́vat, aniǵ by probநl proces jeho regenerace. Navzdory faktu, ǵe pojem brownfield je definován v kontextech rTzných evropských zemí odlig̉n (Frantál et al. 2012), v Leské republice existuje základní a vǵeobecnクuznávaná shoda nad definicí tohoto pojmu. Jak uvádí Vyhledávací studie pro lokalizaci brownfieldT v L eské republice, zpracovaná agenturou CzechInvest v letech 2005-2007 (CzechInvest, 2008), na území zemクse nachází 2355 brownfieldT na celkové ploǵe 10326 hektarT, nicmén円kvalifikované odhady hovoŚ o poḷ tech thhto ploch i jejich rozloze v pŚbliǵnク! tyŚísobné míś (aǵ 11700 lokalit o rozloze aǵ 38000 hektarT). Rozmísthí thchto ploch v rámci okresT a regionT Leské republiky zna!̣n nerovnomクné, coǵ je zpTsobeno rozdílným historickým ekonomickým vývojem tḩhto oblastí. Nicménク obecnク lze konstatovat, ǵe hybné síly vzniku brownfields jsou v principu stejné. Od dTsledkT prom円n centrálnク plánované ekonomiky na ekonomiku trǵní od zal átku 90. let 20. století a klesající konkurenceschopnost jednotlivých odv hví, pŚs dŢsledky obecného pŚsunu základních spolel enských paradigmat od spolę nosti industriální k post-industriální, aǵ po dTsledky globálních trendT (napŚ Rydvalová a G̣iǵka, 2006). 
Souvislosti existence brownfieldT nejsou limitovány jen na danou plochu. Jak uvádí Kunc et al. (2014), je nepochybné, ǵe g̉rğ zázemí daného plochy brownfieldu fakt opuġhosti, zanedbanosti ! i

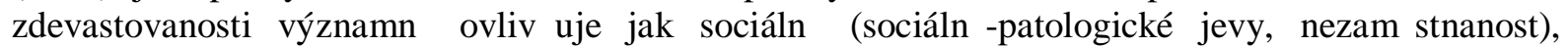
ekonomicky (napŚ sníǵení cen pozemkT a nemovitostí v zázemí - Sun a Jones, 2013) i

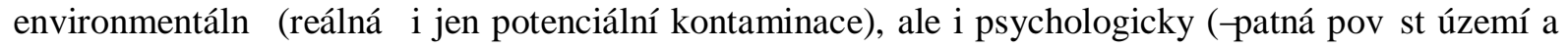
jeho stigmatizace). Vg̉echny tyto souvislosti pJsobí na obyvatelstvo, coǵ ! iní percepci brownfieldT zna! nou specifickou. Jak ve svých studiích o percepci urbánních brownfieldT prokázal Kunc et al.

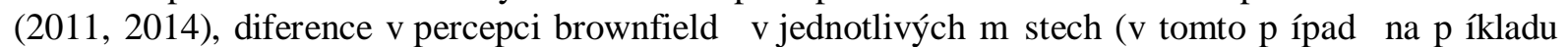
Brna a Ostravy) je dána jednak úsphọností, s jakou $\mathrm{m}$ ḩta prog̉a procesem transformace své ekonomiky v posledních dvou dekádách, ale také vzdநanostní úrovní obyvatelstva, která s pŚedeg̉ým tvrzením úzce souvisí. Kunc et al. (2014) rovnhǵupozorŔje na odlig̉é preference obyvatel týkající se jednotlivých moǵností budoucího vyuğití ploch brownfieldT. Naproti tomu Klusál ek et al. (2011) obrátil svou pozornost $\mathrm{k}$ veŚ́jné správ a jejím postojTm pŚ regenerace brownfields (na pŚkladク Tanvaldska). Ponクkud jiný pŚstup k problematice zvolil Alexandrescu et al. (2014), který na pŚkladగ zkoumání jednotlivých projektT regenerace brownfields v Leské republice, Polsku a Rumunsku a jejich míś podpory veŚjnou správou (a obecnクaktéry) upozorŔuje na zásadní význam lokálních socio-ekonomických podmínek a také na význam systémové ukotvenosti jednotlivých institucí zabývajících se procesem regenerace brownfieldT.

\section{Metodika a pouọ́tá data}

Nezbytným krokem, který musí pŚdcházet úvahám o prostorových souvislostech p\$́dpokladT vzniku a také regenerace brownfieldT, je vybudování databáze tḩhto ploch. S ohledem na neexistenci takovéto centrální databáze na pŚslug̉ných úŚđdech veŚejné správy v Karviné, byla tato databáze budována kombinací nhkolika zdrojT informací. Ġo zejména o databázi brownfieldT vypracovanou agenturou CzechInvest, databázi brownfieldT vedenou na krajském úŚinĐMoravskoslezského kraje (2014) vedenou Agenturou pro regionální rozvoj v Ostrav informace z Integrovaného plánu rozvoje mß̧̧ta Karviná (2008) a podkladové materiály poskytnuté na Magistrátu m\$sta Karviné, coǵ bylo

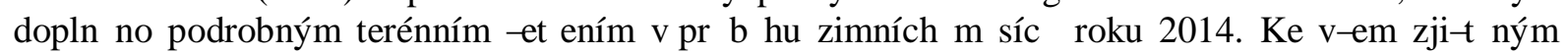
plochám brownfieldT byly pŚŚszovány informace týkají se jejich rozlohy, vlastnictví, dŚvĐğho vyugítí, ale i budoucího plánovaného vyuğití. Pro shromáǵdhí ththto údaj丁 byl vyuğit vedle výǵe uvedených databází také místní tisk. Zjiğ̣né plochy byly roztŚdhyy podle mḩstských !̣ástí, v nichǵ jsou lokalizovány a pro jednotlivé $m$ \$stské Ị ásti byly shromáǵdhny základní socio-ekonomické údaje. V druhé fázi výzkumu bylo realizováno dotazníkové getśní mezi obyvateli Karviné, jehoǵ cílem bylo zjistit jejich názory na místní brownfieldy a preference moǵností jejich regenerace. V pr J̧Đ̧u února a bŚzznu roku 2014 byli oslovováni obyvatelé $\mathrm{m}$ \$̧ta starğ 18 let vulicích $\mathrm{m}$ ḩta. Celkem bylo provedeno 150 semi-strukturovaných rozhovorT, pŚ nichǵ byl vyplŔován dotazník obsahující 16 otázek. PŚ identifikace respondentT byla respektována vyváǵená vクková, vzdクanostní a genderová struktura respondentT a míra návratnosti dotazníkT se v dTsledku pŚmého dotazovaní pohybovala okolo $90 \%$. Pro identifikaci pŚedpokladT vzniku brownfieldT v Karviné byla vyuǵita literaturu zabývající se vývojem a specifiky industrializace území Karvinska (Dohnal 1968, Kijonka a Rebrová 2005, Chmiel 2010).

\section{PSedpoklady vzniku brownfieldT v Karviné}

Karviná je slezským mß̧tem ve východní |̣ ásti L Leské republiky, kde na plog̉e 57,5 hektarT ğje 57 tisíc obyvatel (2014). Významným specifikem $\mathrm{m} h$ ta je hornictví a thǵký prTmysl, které jiǵ více neǵ 150 let formují zdejğ specifické urbánní struktury (hromadné formy bydlení jak ve form门starých hornických kolonií, tak panelových sídliğ̌s, ve kterých v soul asné dobクğije více neǵ $90 \%$ obyvatel $\mathrm{m}$ \̧̧ta), ale i demografické a sociální struktury. Tento dlouhodobý trend koexistence $\mathrm{m}$ 乃̧ta, hornictví (a thớkého prTmyslu) a masové imigrace obyvatelstva v dekádách thóebního boomu, jehoǵpoḷ átky lze spatŜvat jiǵ od poḷátkT industrializace na konci první poloviny 19. století, zanechal své stopy

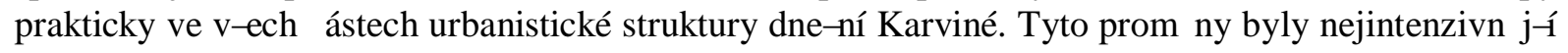
v období centráln Đplánované ekonomiky v dTsledku masivní podpory thớby uhlí a thókého prTmyslu 
na úkor ostatních odvhví v období socialismu. Nejdrastil thğ projevy za sebou zanechala thğba v mßtské !̣asti Doly (dŚvクğ centrum Karviné), které bylo v 50.-60. letech 20. století v dJsledku

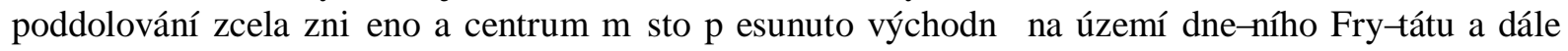
v mß̧tských ! ástech Louky a Darkov (v jiǵním sektoru mß̧ta). Po spolel ensko-politických zm hách v roce 1989 dochází k dramatickému omezování thớby v ostravské !̣ ásti Ostravsko-karvinského revíru a centrum thóby se pŚsouvá na Karvinsko, kde dnes spolẹ nost OKD provozuje dva doly ï DT

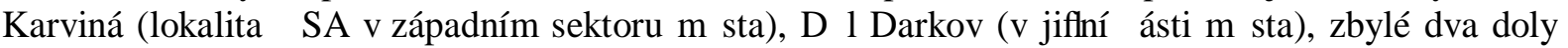
(DTI L SM, DJl Karviná ï lokalita Lazy) jiǵ leǵi na katastrech sousedních obcí (Stonavy a Orlové), nicménク i jejich dT̄ní pole na území Karviné zasahují. OKD je dodnes nejvýznamnクğm zamß̧tnavatelem nejen v Karviné, ale patŚ s cca 17 tisíci zamß̧̧tnanci k i nejvýznamn円ğm zam \$tnavatelTm v Moravskoslezském kraji. O významu industriálních aktivit ve $\mathrm{m}$ \$t门 hovoŚ zam \$̧tnanost v prTmyslu, která jeg் na zaḷátku 90. let 20. století tvoŚla 50,3\% ekonomicky aktivního obyvatelstva, dodnes se snígila o tém斻olovinu (26,5\% v roce 2011$)$, nicmén円pŚsto stále tvoŚ významnou poloǵku v zamß̧tnanosti obyvatelstva. V tomto kontextu je nezbytné zmínit velmi vysokou míru nezamß̧̧nanosti $(14,4 \%$ na konci roku 2013), která v kombinaci s místním silnך znel iğhným ğivotním prostŚdí vytváŚ pŚdpoklady pro silnou emigraci obyvatelstva do jiných mß̧t a regionT L Leské republiky (za poslední tŚ dekády klesl pol et obyvatel Karviné o $27 \%$ ). Je nezbytné zmínit i tradici karvinské kovovýroby a strojírenství, ale i ǵelezáŚství (Kavoz, Kovona, Jäkl), jejichǵ tradice je také v území mß̧̧ta jiǵ více neǵ stoletá.

\section{Prostorová analýza brownfieldȚv Karviné}

Na území mß̧ta Karviné bylo na základクvýğe uvedených databází a provedeného terénního ġeśéní zjiğhno na celkové rozloze 120 hektarT 28 ploch, které lze oznal it jako brownfieldy. Je nutné podotknout, ǵe dTsledky thŏby uhlí ve sledovaném prostoru (poklesy terénu v dTsledku poddolování, zmhny hydrologických pomnT atd.) se nekryjí pouze s vymezenými brownfieldy (areály dolT a podnikT), zejména $\mathrm{v} m$ \$̧tských ! ástech Doly, Darkov a Louky jde o území mnohem g̈rğ, nicménク pro úl ely tohoto výzkumu byly nebyly s ohledem na svá specifika a nejasné vymezení tyto rozsáhlé plochy brány v úvahu. Vyjdeme-li k tohoto tvrzení, pokrývají zjig̉né brownfieldy $2,1 \%$ rozlohy

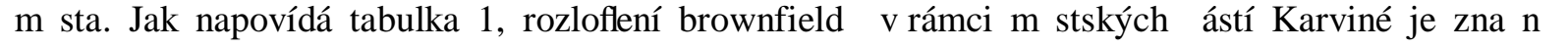
nerovnomltné.

Tab. 1: Brownfieldy v mß̣tských !̣ástech Karviné

\begin{tabular}{|c|c|c|c|c|c|c|}
\hline $\begin{array}{l}\text { mßştská } \\
\text { lást }\end{array}$ & $\begin{array}{c}\text { pol et } \\
\text { brownfieldT } \\
(2014)\end{array}$ & $\begin{array}{l}\text { rozloha } \\
\text { brownfieldT } \\
(2014, \text { ha })\end{array}$ & $\begin{array}{c}\text { podíl na rozloze } \\
\text { mhstských I’ástí } \\
(\%)\end{array}$ & $\begin{array}{c}\text { podíl na celkové } \\
\text { rozloze brownfields ve } \\
\mathrm{m} \cap \mathrm{s} \mathrm{t}(\%)\end{array}$ & \multicolumn{2}{|c|}{$\begin{array}{c}\text { rozloha a pol et } \\
\text { obyvatel } \\
(2011) \\
\text { (obyvatel; km2) }\end{array}$} \\
\hline Darkov & 1 & 3 & 0,6 & 2,5 & 301 & 541,8 \\
\hline Doly & 8 & 50,78 & 3,1 & 42,0 & 325 & 1643,4 \\
\hline Fryğát & 2 & 0,7 & 0,3 & 0,6 & 1547 & 256,1 \\
\hline Hranice & 5 & 13,21 & 5,1 & 10,9 & 8152 & 259,5 \\
\hline Louky & 3 & 3,43 & 0,3 & 2,8 & 407 & 991,7 \\
\hline $\begin{array}{l}\text { Nové } \\
\text { Mß̧sto }\end{array}$ & 4 & 26,1 & 10,9 & 21,6 & 17163 & 240,1 \\
\hline Ráj & 2 & 18,8 & 2,4 & 15,5 & 16088 & 771,3 \\
\hline $\begin{array}{l}\text { Staré } \\
\text { Mß̧sto }\end{array}$ & 3 & 4,97 & 0,6 & 4,1 & 810 & 849,9 \\
\hline Mizerov & 0 & 0 & 0 & 0,0 & 12077 & 198,3 \\
\hline
\end{tabular}

Zdroj: databáze brownfield丁 agentury CzechInvest, databáze brownfield T Moravskoslezského kraje, Integrovaný plán rozvoje mnsta Karviná (2008), podkladové materiály poskytnuté Magistrátemu m nsta Karviné, vlastní terénní getŚsí

Nejvíce brownfieldT se nachází na území $m$ ḩtské lásti Doly, coǵ je území v západní lásti sledovaného prostoru, které se kryje s dŚvĐğ lokalizací p Jvodního centra Karviné. Zde se tyto plochy rozkládají na témగśs 51 hektarech a jde zejména o plochy, jejichǵ dŚvĐğ funkce mワa souvislost s místní dlouholetou thóbou !erného uhlí. Je zde moǵné nalézt areály bývalých dolT (JindŚch, 
Gabriela, Barbora a jiné), bývalé hornické kolonie (U Frantig̉ky, U Barbory), li areály v rámci stávajících dolT, jejichǵ funk! nost je omezená !̣i jsou zcela opuğhny (autobusové nádraği u Dolu L,SA, koksovna stejného dolu atd). Jak vyplývá z tabulky 2, v území mḩtské ! ásti Doly góje velmi malý poḷ et obyvatel a ohledem na jeho perifernost jejich pol et neustále klesá (v posledních 20 letech o $75 \%$ - viz tabulka 2). Mezi obyvatelstvem tohoto území, kde je majoritním vlastníkem pozemkT i

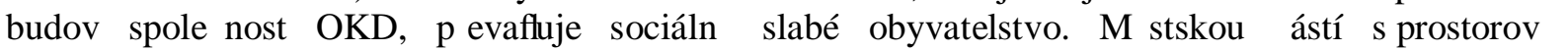
významnými brownfieldy (tvoŚ více, neǵ phinu rozlohy brownfieldT v Karviné) je i Nové Mß̧to.

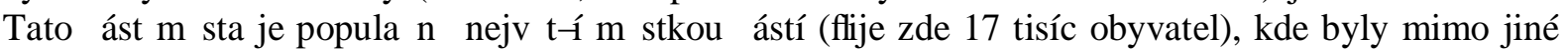
soust ́́d円yy rozsáhlé prTmyslové provozy karvinského podniku Kovona, která se soust\$́Novala na kovovýrobu. Její nástupce pod stejnojmenným názvem funguje v omezené míśe dodnes, nicménந! ást reálu pod názvem PrTmyslový park (na ulici Závodní) je vyuğ́ián jen v omezené míś. Z dalğ́ch

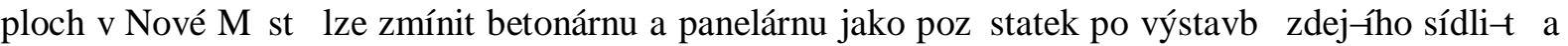
kulturní dJm Kovony, který býval vyuğ́ván pro organizaci spolel enský akcí, nicménクv soul asné

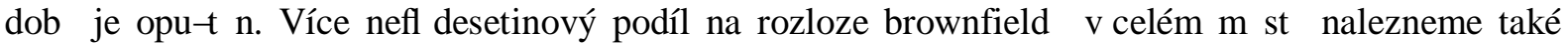

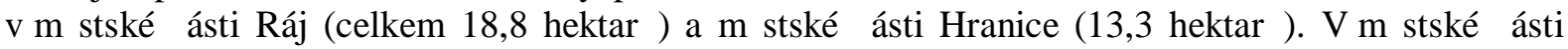
Hranice se jedná p§̧devğm o plochy po prTmyslu (!̣ ást areálu Jakl ḷ i bývalý Okresní stavební podnik) ! i po bydlení (Vagónka Ï p丁vodnク vilová Ị tvrŠ pro úśdníky Jäklových ǵelezáren z 20. let 20. století, poté na dlouhá léta bydlení pro sociálnh slabé, v roce 2011 zboŚno). Odliğný typ brownfieldT

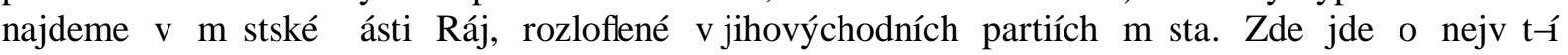
registrovaný brownfield $\mathrm{v}$ rámci $\mathrm{m}$ \̧ta $(15,5$ hektarT), a to areál bývalé posádky protivzduğné obrany Armády L,eské republiky pod názvem Ḷený les a místní zemßạnskou farmu. V centrální ! ásti Karviné, tedy v mḩtské !̣ásti Fryğát, najdeme pŚedevğm brownfieldy, které mají historickoarchitektonickou hodnotu (Janál kJv mlýn a Larischovy konírny).

Tab. 2: Vybrané charakteristiky $m$ ßstských ḷástí Karviné

\begin{tabular}{|c|c|c|c|c|c|c|}
\hline $\begin{array}{l}\text { mß ̧̧tská } \\
\text { l ást }\end{array}$ & $\begin{array}{l}\text { hustota } \\
\text { zalidnhíi } \\
(2011, \\
\text { obyvatel } \\
\left./ \mathrm{km}^{2}\right)\end{array}$ & $\begin{array}{c}\text { zm/ha pol tu } \\
\text { obyvatel } \\
(2001-2011, \mathrm{v} \\
\%)\end{array}$ & $\begin{array}{c}\text { zm/ha poḷ tu } \\
\text { obyvatel }\end{array}$ & $\begin{array}{c}\text { zmß̧a po! tu } \\
\text { dom丁 } \\
(2001-2011, \mathrm{v} \\
\%)\end{array}$ & $\begin{array}{c}\text { index stáS } \\
(2011, \\
65+/ 0-14)\end{array}$ & $\begin{array}{c}\text { podíl } \\
\text { ekonomicky } \\
\text { aktivního } \\
\text { obyvatelstva } \\
\text { (2011) }\end{array}$ \\
\hline Darkov & 55,6 & $-25,9$ & $-74,8$ & $-19,0$ & 191,7 & 45,2 \\
\hline Doly & 19,8 & $-59,9$ & $-75,0$ & $-54,0$ & 84,9 & 37,2 \\
\hline Fryğát & 604 & 8,5 & 13,0 & 9,8 & 169,0 & 43,8 \\
\hline Hranice & 3141 & $-9,4$ & $-18,8$ & 17,8 & 125,4 & 45,9 \\
\hline Louky & 41 & $-10,2$ & $-39,1$ & $-6,2$ & 204,8 & 46,9 \\
\hline $\begin{array}{l}\text { Nové } \\
\text { Mßşto }\end{array}$ & 7149,5 & $-11,6$ & $-11,4$ & 1,0 & 111,6 & 41,9 \\
\hline Ráj & 2085,9 & $-14,1$ & $-14,5$ & 7,6 & 153,5 & 46,7 \\
\hline $\begin{array}{l}\text { Staré } \\
\text { Mņ̧to }\end{array}$ & 95,3 & $-5,3$ & 0,0 & 6,8 & 142,7 & 45,7 \\
\hline Mizerov & 6089,9 & -14 & $-18,5$ & 0,4 & 137,8 & 47,1 \\
\hline Karviná & 988,7 & $-12,7$ & $-16,9$ & 1,2 & 132,0 & 45,1 \\
\hline
\end{tabular}

Tabulky 3-6 nabízí dalğ pohled na brownfieldy v Karviné podle nejrTznクğch kategorií. Z analýzy databáze vyplývá, ǵe nej! etn円i vyskytujícím se brownfieldem je zde velikostní kategorie 1-3 hektary, nicménクz pohledu celkové rozlohy brownfieldT v jednotlivých velikostní kategoriích lze konstatovat, ǵe nejvíce prostoru (více neǵ pクjinu) zabírají ploch o velikosti 5-10 hektarT. Nej! astクğ pśedchozím vyuğitím stávajících ploch brownfieldT v Karviné je pol etnクi rozlohou prTmysl (viz tabulka 4). Tato informace není nijak pŚkkvapivá. Je vğłk nutné podotknout, ǵe absence poddolovaných ploch jako následku thğby uhlí v území stojí mimo analyzovanou databázi, a proto tedy brownfieldy po thóbク zabírají Ăjenñ necelou tŚ́tinu brownfieldových ploch, zejména v jiǵ zmínhém Darkov円a Dolech. V kontextu dramatických propadT zemhanjských aktivit v posledním období není pŚ́kvapivý výskyt

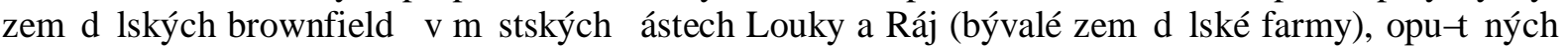
skleníkT ve Starém Mhț Do stejné kategorie jsou Śzeny i historicky cenné Larischovy konírny (Fryğát). PŚ́dchozí vyuğití ve sluğbách (tabulka 4) bylo identifikováno ve ḷ tyŚech pŚpadech, nicmén円 
jejich Śzzení do této kategorie je znal nךvariabilní s ohledem na jejich specifika (autobusové nádrağ u Dolu L SA v Dolech, opug̣ hý kostel sv. Barbory v poddolované !ásti mß̧tské !ásti Louky !i vodárenská v'ğ́ v mhstské ! ásti Hranice). Do jisté míry mají tedy i tyto plochy souvislost s prTmyslovými a thóebními aktivitami. Jakkoli nepŚchledná je situace karvinských brownfieldT

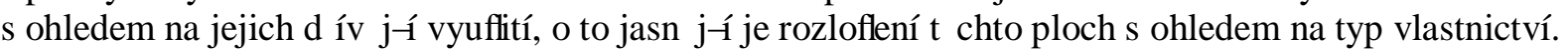

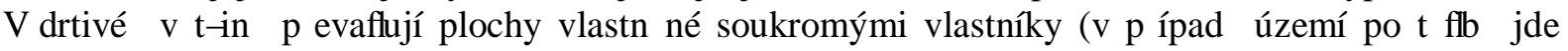
témగŚvýhradnךo vlastníka místních dolT, spole! nost OKD), brownfieldy ve veŚjném vlastnictví byly identifikovány pouze dva (Larischovy konírny ve Fryǵátク a Vagónka v Hranicích). Smígené vlastnictví brownfieldT je v Karviné spíge výjimkou a týká se areálT v okolí bývalého dolu Barbora v mhtské ! ásti Doly.

Tab. 3: Brownfieldy v Karviné podle velikostních kategorií

\begin{tabular}{|l|c|c|c|c|c|}
\hline podle velikosti & do 1 ha & $1-3$ ha & $3-5$ ha & $5-10$ ha & 10 a více ha \\
\hline pol et ploch & 3 & 11 & 6 & 5 & 4 \\
\hline rozloha ploch (ha) & 1,5 & 20,5 & 21,9 & 25,7 & 51,4 \\
\hline podíly rozlohy ploch (\%) & 1,2 & 16,9 & 18,1 & 21,2 & 42,5 \\
\hline
\end{tabular}

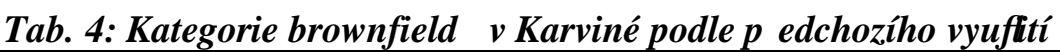

\begin{tabular}{|l|c|c|c|c|c|c|c|}
\hline podle pŚdchozího vyugóití & kultura & bydlení & thóba & prTmysl & sluǵby & armáda & zem \łnství \\
\hline pol et ploch & 1 & 3 & 5 & 9 & 5 & 1 & 4 \\
\hline rozloha ploch (ha) & 1 & 9,7 & 37,9 & 42,2 & 7,14 & 15,5 & 7,6 \\
\hline podíly rozlohy ploch (\%) & 0,8 & 8,0 & 31,3 & 34,9 & 5,9 & 12,8 & 6,3 \\
\hline
\end{tabular}

Zdroj: vlastní výzkum i zpracování

Tab. 5: Kategorie brownfieldT v Karviné podle typu vlastnictví

\begin{tabular}{|l|c|c|c|}
\hline podle typu vlastnictví & smíğené & soukromé & veŚjné \\
\hline pol et ploch & 3 & 23 & 2 \\
\hline rozloha ploch (ha) & 19,9 & 97,1 & 4 \\
\hline podíly rozlohy ploch (\%) & 16,4 & 80,2 & 3,4 \\
\hline
\end{tabular}

Pohled na kategorie brownfieldT v Karviné podle intenzity souḷ asného vyuğití a kontaminace nabízí tabulka 6. AlespoŔ lásteḷ né vyugótí ploch bylo identifikováno v pŚpadクjen jedné tŚ́tiny ploch. Jde výhradnクo plochy dŚve vyuğivané pro jiné neǵ thóební úl ely (zejména plochy po prTmyslu, ale i zemßīství). Lze konstatovat, ǵe vyuğ́vání thgóebních brownfieldT je znal né specifické a problematické jednak s ohledem na jejich periferní polohu v rámci zkoumaného území, tak s ohledem na environmentální problémy, které výskyt tohoto typu ploch provází (jiǵ zmínnhé poddolování a související poklesy, zamokŚní ploch v dTsledku zmß̧ hydrologie území ḷi kontaminace). Tuto

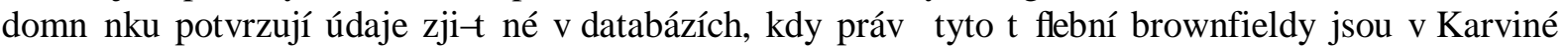
oznal eny jako ty s pśdpokládanou kontaminací (viz tabulka 6).

Tab. 6: Kategorie brownfieldT v Karviné podle sou!̣asného vyuğtí a kontaminace

\begin{tabular}{|l|c|c|l|c|c|}
\hline $\begin{array}{l}\text { podle soul asného } \\
\text { vyuǵití }\end{array}$ & $\begin{array}{c}\text { lástel } \mathrm{n} \eta \\
\text { vyuǵtito }\end{array}$ & nevyuǵito & $\begin{array}{l}\text { podle } \\
\text { kontaminace }\end{array}$ & pŚdpokládaná & nepŚdpokládaná \\
\hline pol et ploch & 9 & 19 & pol et ploch & 10 & 18 \\
\hline $\begin{array}{l}\text { rozloha ploch } \\
\text { (ha) }\end{array}$ & 36,9 & 84,1 & $\begin{array}{l}\text { rozloha ploch } \\
\text { (ha) }\end{array}$ & 60,3 & 60,7 \\
\hline $\begin{array}{l}\text { podíly rozlohy } \\
\text { ploch (\%) }\end{array}$ & 30,5 & 69,5 & $\begin{array}{l}\text { podíly rozlohy } \\
\text { ploch (\%) }\end{array}$ & 49,8 & 51,2 \\
\hline
\end{tabular}

Obrázek 1 prezentuje prostorové rozmíst hí jednotlivých brownfieldT v Karviné v závislosti na jejich konkrétní lokalizaci v rámci $\mathrm{m} \$ \mathrm{ta}$, jejich velikosti, pŚedchozím vyuğití, typu vlastnictví a

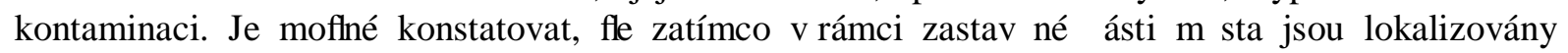
brownfieldy, jejichǵ dŚvĐğ vyuğití bylo vhg̉nou v prTmyslu (jak pŚedevğm ve strojírenství, tak i 
menğ míś v energetice ḷi potravináŚství), thğební brownfieldy jsou umísthy v západní !̣ásti území

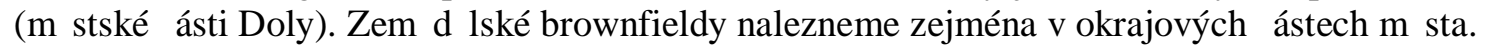

\section{Obr. 1: Lokalizace a charakteristiky identifikovaných brownfieldT v Karviné}
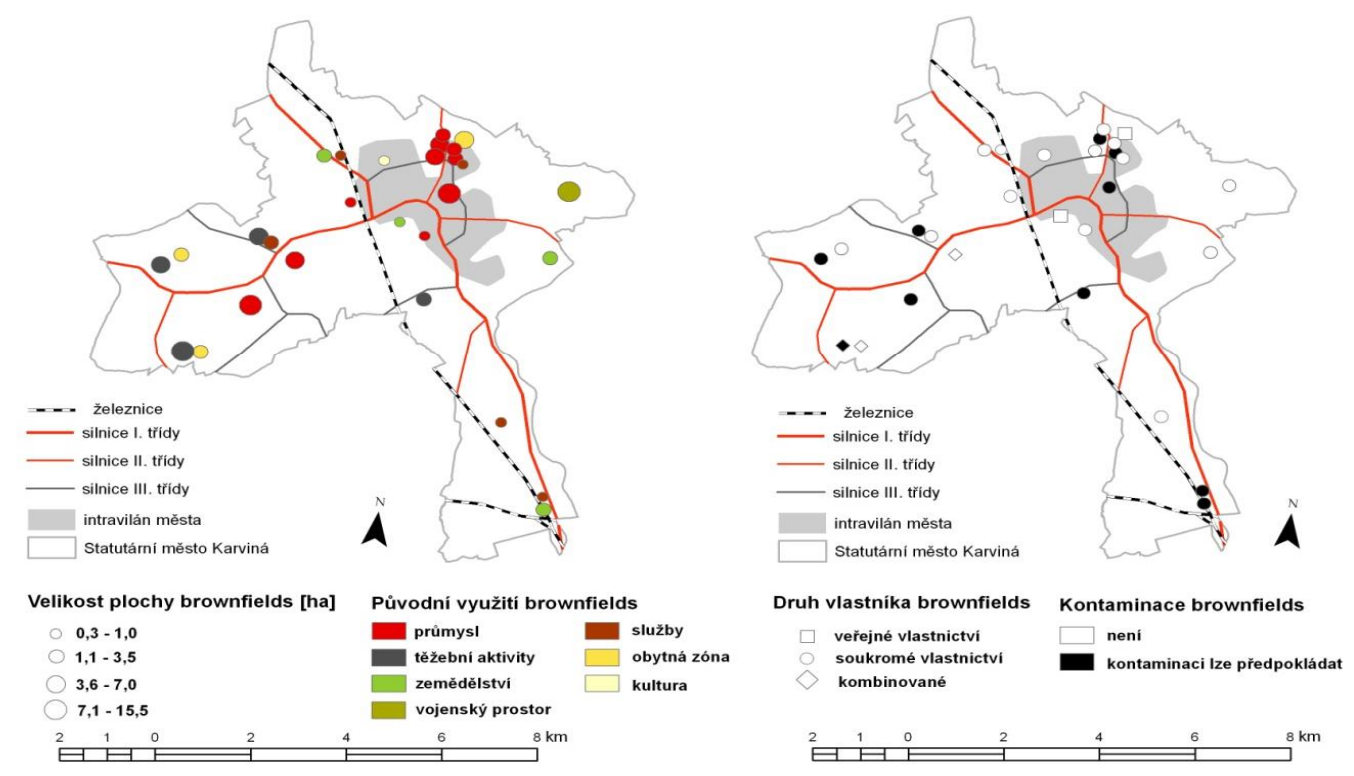

Zdroj: vlastní výzkum i zpracování

\section{Výsledky dotazníkového ġtSení}

Nedílnou souḷástí výzkumT týkajících se problematiky brownfieldT je jejich percepce místním obyvatelstvem. V tomto $\mathrm{pŚsphyku} \mathrm{jsou} \mathrm{s} \mathrm{ohledem} \mathrm{na} \mathrm{omezený} \mathrm{rozsah} \mathrm{analyzovány} \mathrm{odpovhdi} \mathrm{pouze} \mathrm{na}$ dvク otázky (z celkových 16) uvedené v dotazníkovém getŚní. První hodnocená otázka smb̧́vala k identifikaci konkrétní lokality, která se respondentTm vybaví s souvislosti s pojmem brownfield. Otázka byla formulována jako volná a je nutno konstatovat, ğe její hodnocení pŚneslo do znal né míry pŚkkvapivé skutel nosti (viz graf 1). Respondenti v rámci mß̧̧ta oznaḷili celkem 14 lokalit, z nichǵ tém佔 tŚtina respondentT zmiŔovala ve svých odpovhlí lokalitu Vagónka, tedy území, které dŚ́ve slouǵllo pro bydlení a p hina areály Kovony a bývalého Okresního stavebního podniku (OSP). Tento

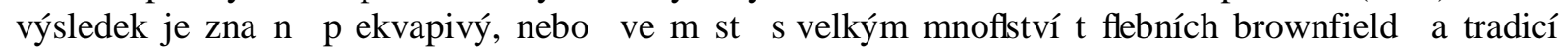

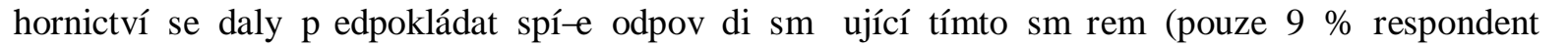
oznal ila bývalý dT̄ Barbora, ostatní thǵební brownfieldy nebyly uvedeny v odpovflích vTbec).

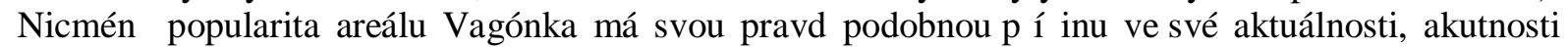
Śgéení a debatách souvisejících s demolicí budov v této lokalith dŚve obývané pŚ́devğm Romy. Dalğm argumentem je periferní lokalizace thǵebních brownfieldT v západním sektoru mhşa, které je

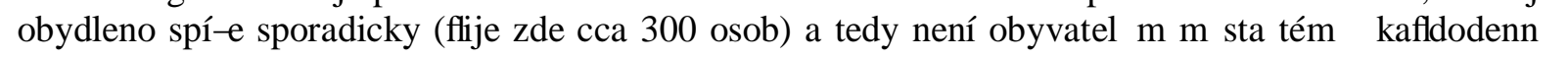
Ăna ol íchñ (na rozdíl od dalğch dvou nej! ast円i zmiŔovaných lokalit). 
Graf 1: PŚ́hled odpov Dlí na otázku: ĂJaká lokalita se vám v Karviné vybaví v souvislost s pojmem brownfield? $\tilde{\mathbf{n}}$

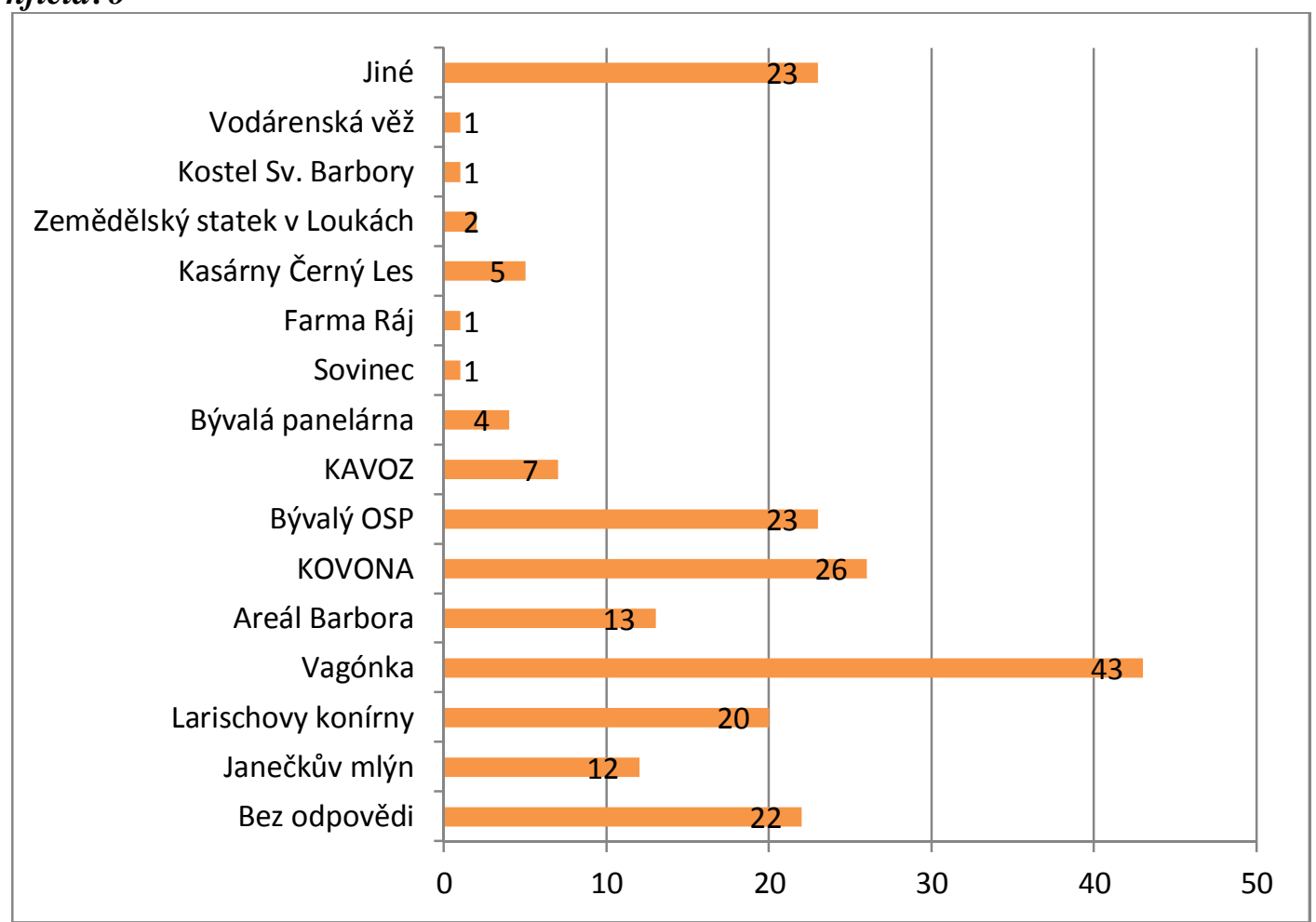

Zdroj: vlastní výzkum i zpracování $(n=150)$

V dalğ otázce jsme se zamhśli na potenciální moğnosti vyuğ́vání thğebních brownfieldT v Karviné, která, jak plyne z výǵe uvedených poznatkT, nejsou mezi obyvateli $\mathrm{m}$ \̧̧ta pŚlig̉ populární. Jednotlivé varianty regenerací byly respondentT pŚkládány ve form门vý! tu. Respondenti poté hodnotili (viz graf 2) !́ísly od 1 do $5(1=$ nejvhğ dTleğitost a $5=$ nejmenğ dTleğitost $)$. Pro kaǵdou $\mathrm{z}$ nabízených moǵnosti byla z výsledkT vypolítána prTm/zná preference respondentT pomocí aritmetického prTm\u. Tedy, ! ím více se výsledná hodnota dané moǵnosti blígila jedné, tím preferovan円ğ to byla moǵnost regenerace. Jak vyplývá z grafu 2, nejvíce preferencí získala moǵnost regenerace thǵebních brownfieldT na nové areály pro výrobu. Tento výsledek lze interpretovat v kontextu sociálních problém丁, vysoké míry nezamß̧tnanosti a nedostatku pracovních pŚleğitostí v Karviné. Druhou nejpreferovanクg் moǵností regenerace thóebních brownfieldT se stala pŚem円a na zelené plochy. Naopak za nejmén円preferovanou moǵnost bylo oznal ováno bydlení. 


\section{Graf 2: Potenciální varianty vyuğvání thébních brownfieldT v Karviné}

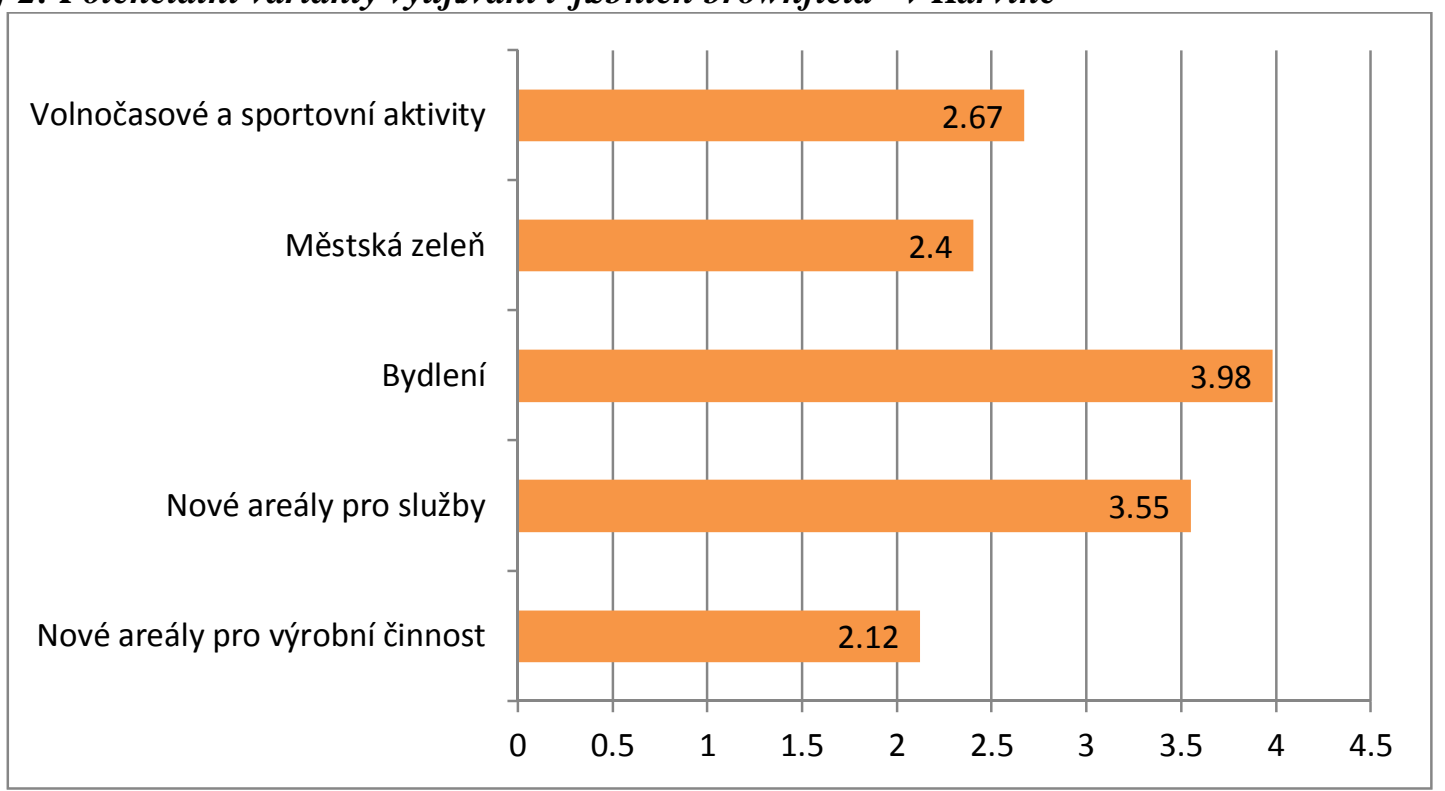

Zdroj: vlastní výzkum i zpracování $(n=150)$

\section{Závn}

V Karviné bylo identifikováno 28 ploch brownfieldT na celkové ploǵe 121 hektarT. Byla provedena analýza vytvoŚené databáze a vytvoŚnny jednotlivé kategorie brownfieldT podle pŚedchozího vyugóití, stávajícího vyugoití, vlastnictví ḷi velikosti. Zatímco brownfieldy po thớbりjsou v dTsledku pŚrodních podmínek a historického vývoje lokalizovány pŚedevğm v jiğních a západních periferních partiích Karviné ( $\mathrm{m}$ ḩtské !̣ásti Darkov a Doly), prTmyslové brownfieldy nalezneme v blízkosti pásu panelových sídliğš vybudovaných v období socialismu (Nové Mß̧to, Hranice). Specifikem centrálních partií $\mathrm{m}$ ḩta (Fryǵát) jsou brownfieldy s významným architektonickým a kulturním dhlictvím (Janál kTv mlýn, Larischovy konírny). Provedené dotazníkové ġeś́ní potvrdilo relevantnost p§́dpokladu, ǵe urbánní brownfieldy tvoŚ významný prvek ve strukturách $\mathrm{m}$ \̧̧ta a obyvatelstvo jejich existenci vnímá velmi intenzivnn $\mathrm{Na}$ druhou stranu je moǵné konstatovat, ğ́ vnímání budoucnosti thǵebních brownfieldT v Karviné je znal $\mathrm{n} \eta$ problematické, neboŠ jsou velmi silnク spojovány s prTmyslovými aktivitami jako nejpreferovanクğ variantou nového vyugití. Nicménク pravdధpodobnost masového vyuğití této varianty je velmi nízká s ohledem na dostupnost existujících prTmyslových zón v rámci intravilánu mḩta (PrTmyslový park v Novém Mß̧ta !̣i PrTmyslová zóna Nová Pole ve Starém Mß̧tク. Je otázkou, nakolik je plánovaná výstavba prTmyslové zóny Nad Barborkou v mßstské !̣ásti Doly (a její naplnhní investory) realitou, !̣i jen politickou proklamací pŚdstavitelT $m$ ḩ̧ta a kraje.

Regenerace brownfieldT je ġroce diskutovanou tématikou, která v souvislosti se stále intenzivnクğm

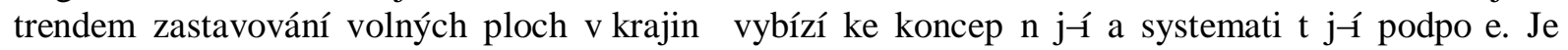
nepochybné, ǵe v regionech s koncentrací sociálních, ekonomických a environmentálních problém丁, jako je tomu napŚklad na Karvinsku, je zájem soukromých investorT o investice do regenerací brownfieldT velmi omezený. O to dTleǵtĐğ jsou zde projekty veŚejné správy, které by mクy fungovat jako vzorové a vybízet soukromé investory k obdobným investicím. Je nepochybné, ǵe vzdクávání

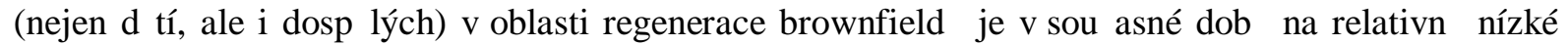
úrovni a právĐosvha upozorŔující na environmentální, ale i sociální problémy koncentrující se v území s existencí brownfieldT, stále do velké míry chybí. Chybí také koncep! ní politika státu a m \$̧t zamrśená na alespoŔ prozatímní vyuǵ̛vání ploch brownfieldT v pŚpadech, kdy to hygienické a environmentální podmínky dovolují (Haase a Rall, 2011; Martinát et al., 2014). Na tomto místĐlze zmínit n kolik projektT regenerace brownfieldT, které byly jiǵ v Karviné realizovány, a které vzbudily rozsáhlé diskuse o jejich prosplğhosti. Zatímco projekt PrTmyslové zóny Nové Pole ve Starém Mḩ̣th je v kontextu stovek novクvytvoŚných pracovních míst vnímán velmi pozitivnク výstavba golfového 


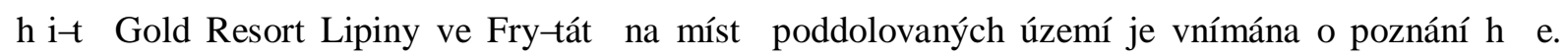

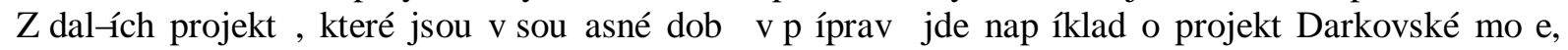
jehoǵ cílem je vybudování rekreal ní zóny okolo um\ého jezera v mß̧̧tské ! ásti Darkov, která byla tróce postiǵena thóebními aktivitami. Zajímavým je i pŚpravovaný projekt pod názvem ÂPo stopách pTvodní Karvinéñ jehoǵ cílem je vybudovat nau! né stezky a cyklostezky v oblastech postiǵených

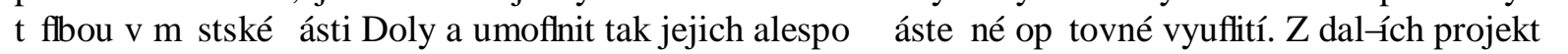
lze zmínit jiǵ uvedený plán na vybudování prTmyslové zóny s názvem Nad Barborou oph v mß̧tské ! ásti Doly. Závクem je nezbytné dodat, ǵe i v pŚpadク vyuớvání území s thğebními brownfieldy !̣i areály je nezbytné brát v úvahu také environmentální aspekty jejich nového vyuğití tak, aby jejich regenerace stávající neuthg̉ený stav jeġクvíce nenarug̉ly. PŚ plánování, pŚpravĐprojektT regenerace, pS jejich realizaci i následném provozu je také nezbytné brát v potaz názory místních obyvatel a varianty nového vyugóití thhto ploch g̈roce diskutovat s veŚjjností, aby bylo nové vyugóití ploch akceptováno a tím ulehl eny poḷ átky jejich Ănovéhoñ vyuǵ̛vání

\section{Literatura}

[1] ALEXANDReSCU, F., MARTinÁt, S., KLUSÁLtEK BARTKE, S., (2014). The Path From Passivity Toward Entrepreneurship: Public Sector Actors in Brownfield Regeneration Processes in Central and Eastern Europe. Organization \& Environment. ISSN 1086-0266. DOI 10.1177/1086026614529436.

[2] CZECHINVEST., (2008). Národní strategie regenerace brownfieldT. Praha: Ministerstvo prTmyslu a obchodu.

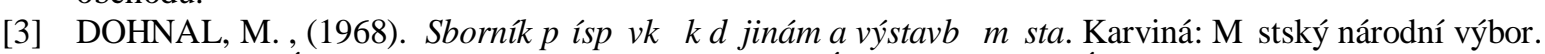

[4] DOLEG̣ElOVÁ, L., HADLAL, M., KADLECOVÁ, M., MARTINÁT, S., POLEDNIK, M., (2014). Redevelopment potential of brownfields: A-B-C model and its practical application. E+M Ekonomie a managemen, 2014, vol. 18, iss. 2 (in print). ISSN 1212-3609.

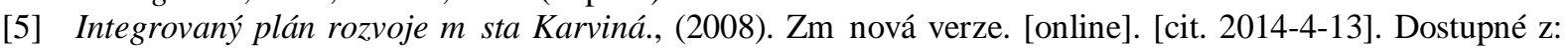
<http://www.karvina.cz/portal/page/portal/uvodni_stranka/magistrat/zakladni_dokumenty/rozvoj_mesta/IN TEGROVAN\%C3\%9D\%20PL\%C3\%81N\%20ROZVOJE\%20M\%C4\%9ASTA\%20KARVIN\%C3\%81.pd $\mathrm{f}>$.

[6] Databáze brownfields Moravskoslezského kraje., (2012). [online]. [cit. 2014-4-14]. Dostupné z: <http://podnikatel.kr-moravskoslezsky.cz/databaze_brownfields.html>.

[7] FRANTÁL, B., KLUSÁL̦EK, P., KUNC, J., MARTINÁT, S. Report on results of survey on brownfield regeneration and statistical analysis. Deliverable D3.1 of the TIMBRE FP7 project no. 265364 - Tailored Improvement of brownfileds regeneration in Europe - www.timbre-project.eu.

[8] FRANTÁL, B., KUNC, J., NOVÁKOVÁ, E., KLUSÁL̨EK, P., MARTINÁT, S., OSMAN, R., (2013). Location Matters Exploring Brownfields Regeneration in a Spatial Context (A Case Study of the South Moravian Region, Czech Republic). Moravian Geographical Reports, vol. 21, iss. 2, p. 5-19. ISSN 1210 8812. DOI 10.2478/mgr-2013-0007.

[9] HAASE, D., RALL, E. L., (2011). Creative intervention in a dynamic city: A sustainability assessment of an interim use strategy for brownfields in Leipzig, Germany. Landscape and Urban Planning, vol. 100, iss. 3, pp. 189-201. ISSN 0169-2046. DOI 10.1016/j.landurbplan.2010.12.004.

[10] CHMIEL., (2010). J. Karviná ï Darkov. L̦eský Thớn: Pro Print. ISBN 80-238-7442-X.

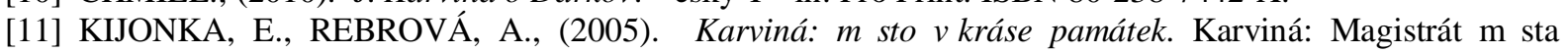
Karviné. ISBN 80-239-5483-0.

[12] KRZYSZTOFIK, R., KANTOR-PIETRAGA, I., SPÓRNA, T., (2013). A dynamic approach to the typology of functional derelict areas (sosnowiec, Poland). Moravian Geographical Reports, vol. 21, iss. 2, pp. 20 ï 35. ISSN 1210-8812. DOI 10.2478/mgr-2013-0008.

[13] KLUSÁLeK, P., KREJḶí, T., MARTINÁT, S., KUNC, J., OSMAN, R., FRANTÁL, B., (2014). Regeneration of agricultural brownfields in the Czech Republic ï case study of the Czech Republic. Acta Universitatis Agriculturae Mendelulianae Brunensis. 2013, vol. 61, no 2, p. 549-561. ISSN: 1211-8516

[14] KLUSÁL̨EK, P., KREJḶ̂́, T., KUNC, J., MARTINÁT, S., NOVÁKOVÁ, E., (2011). The post-industrial landscape in relation to local self-government in the Czech Republic. Moravian Geographical Reports, vol. 19, iss. 4, pp. 8-28. ISSN 1210-8812.

[15] KUNC, J., KLUSÁL̨EK, P., MARTINÁT, S., (2011). Percepce a lokalizace urbánních brownfields: podobnosti a rozdíly na pŚkladu Brna a Ostravy. Urbanismus a územní rozvoj, vol. 14, iss. 1., pp. 13-17. ISSN 1212-0855.

[16] KUNC, J., KUNC, J., NAVRÁTIL, J., TONEV, P., FRANTÁL, B., KLUSÁLtEK, P., MARTINÁT, S., HAVLÍLEK, M., LLERNÍK, J., (2014). Perception of urban renewal: Reflexions and coherences of sociospatial patterns (Brno, Czech Republic). Geographia Technica, vol. 9, iss. 1, pp. 66 - 77. ISSN 1842-5135 
[17] KUNC, J., KUNC, J., MARTINÁT, S., TONEV, P., FRANTÁL, B., (2014). Destiny of urban brownfields: Spatial patterns and perceived consequences of post-socialistic deindustrialization. Transylvanian Review of Administrative, vol. 41, iss. E, pp. 109 ï 128. ISSN 1842-2845

[18] MARTinÁt, S., MARTINÁT, S., Kř EJḶí, T., KLUSÁL̦EK, P., DOHNAL, T., KUNC, J., (2014). Brownfields and tourism: contributions and barriers from the point of view of tourists. Proceedings of conference Public recreation and landscape protection - with man hand in hand? (RaOP 2014). Brno: Mendel University, Brno.

[19] RYDVALOVÁ, P., G̣TG̣KA, M., (2006). Ekonomické souvislosti revitalizace brownfields. Politická ekonomie, vol. 5, pp. 632-644. ISSN 0032-3233.

[20] SUN, W., JONES, B., (2013). Using multi-scale spatial and statistical analysis to assess the effects of brownfield redevelopment on surrounding residential property values in milwaukee county, USA. Moravian Geographical Reports, vol. 21, iss. 2, pp. 56-64. ISSN 1210-8812.

[21] VOJVODÍKOVÁ, B., POTUG̣NÍK POTUG̣NÍK, M., BÜRGERMEISTEROVÁ, R., (2011). The database on brownfields in ostrava (Czech Republic): Some approaches to categorization. Moravian Geographical Reports, vol. 19, iss. 4, pp. 50-60. ISSN 1210-8812.

PŚsphek byl zpracován v rámci projektu financovaného programem Omega Technologické agentury Leské republiky pod názvem ĂWové metody zefektivnhí regenerace brownfields umoǵRujicí optimalizaci rozhodovacích procesȚñ (TD020259). PŚspధek vznikl také s institucionální podporou Ústavu geoniky AV L̦R, v.v.i. (RVO:68145535). 